\title{
CONF-7 $40925-6$
}

INCIPIENT SUPERHEAT IN A CONVECT IVE SODIUM SYSTEM

by

R. E. Henry, R. M. Singer, D. J. Quinn, and W. C. Jeans

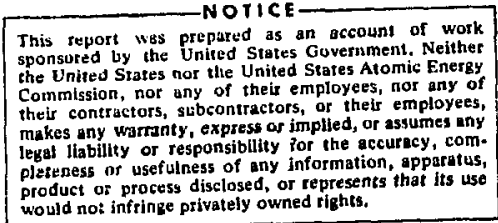

would no: infringe privately owned tights.

For Presentation At:

5th International Heat Transfer Conference, Tokyo, Japan, September 2-7, 1974

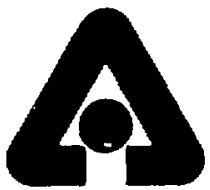


R. L. lienry, R. M. Stnger, D, J, Oulitn, and W. C. Jeans Algonme Sitiollol Laborarory, Arsitunc, Illitois

\section{Abstract}

Experimental measuruments are reported for incipient boiling superheats in a convective sadium system. The resujts stiow that definitive evaluation of the incliplent wil superhit reguires a knowledge of the

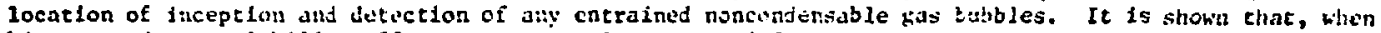
history and gas solubillty effests are properly accouted for, a reatrant cuvicy todel is representafive of the data.

\section{NONENCLATLRE}

C : Concentration

D : Dianeter

h : Heat transfer coeficicient

$k$ : Henry's Law constant

i Thermal conductivity

$P$ : Pressure

$\mathbf{r}$ : Radius

T: Temperature

$\sigma$ : Surface tension

\section{Subseripes}

8 : Gas

h: Hydraul1c

8 : Systea

v Vapor

\section{Superscript}

- deactivation

\section{INIRODUCTION}

Several recent experimental Investigations ${ }^{1-12}$ have been conducted to determine the amount of superheat - 1iquid metal can sustain before hoiling is inttiated. Data have been published in the 11terature ${ }^{2-5}$ which indicate a stroug dependence upon the coolant velocity in the range of $0-2 \mathrm{~m} / \mathrm{sec}, 1 . \mathrm{e.}$. the Inciplent superheat decreases as the velocity Increases. Howerer, experimental results are also aratlable which indicate comparatively high wall cuperheats for velocities in and above this range.6-i? Two general criticisus of the data indicuting a strong velocity cependence have been that vefther the location of inception nor the entralaed gas content were recorded during the experioents. The analysis presented in Ref. 14 11Iustrates the necessfty of detecting the axial locatlon of Inception and the gas infection test. reported In Ref. 15 show that the injection of a aoxcondensable gas bublie into a superheated liquld atel wil inftlate bulk bolling.

The teat scetion for this Irwestigation was instrimented to detect both the axial location of bolling and the eacrained cas content. Thereiore, the relationship between coolant velocity and the incipieat superheat can be definitively cvalusted in the velocity range of interast.

\section{EXPERINENTAL AIPAEITLS}

The facility used for this study is shown schematically in Fig. 1. The details of the test section and all the assacieted instrunentetion are given in Fig. 2, An 0.584 cr: ud sheathed-coll type of heater was used. The hearez element was itichrome $V$

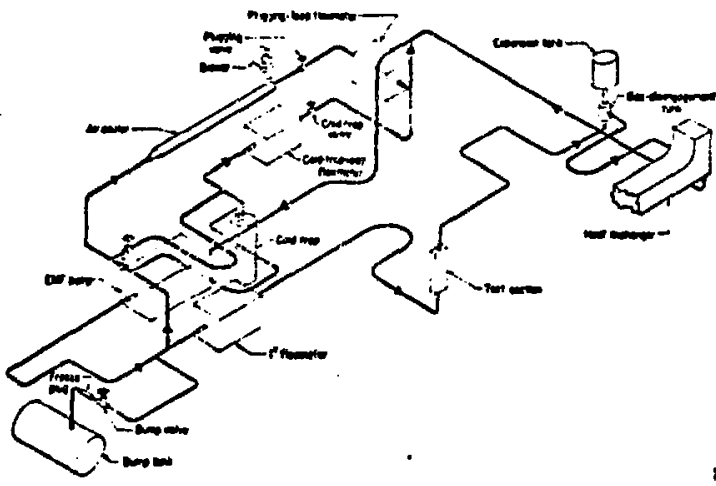

Fis. 1 Basic Loop Schematic

Hre rated for $38 \mathrm{kw}$ at $440 \mathrm{~V}$. Type 316 atainless. teel was used for the sheath, and the downstream end of the heater was grounded to the sodium. A $0.178 \mathrm{~cm}$ OD wire, wrapped on a $30.5 \mathrm{~cm}$ pitch, maintained the annular coolant passage between the heater and the outer wall $(0.953 \mathrm{~cm}$ ID $\times 1.27 \mathrm{Co}$ OD).

In addition to the otandard measurements of pressure, temperature, heater power, and flow rate, two other measurements were taken which proved to be valuable in analyzing the experimental data.

1) Electrodes were welded onto the outer tube through whtch a sanll (10 appere) DC current could be supplied to the outer wall, wire wrap, heater sheath, and sodium coolant. Voltage taps on the outer vall emabled onc to distinguish between nucleations within the superheated region and bosling Initiation triggered by an entrained noncendensable gas bubble. . 


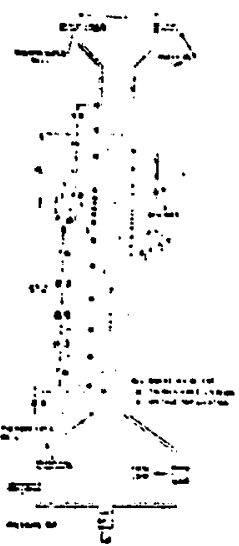

Fig. 2 Test Section

2) A converging-diverging nozzle in the test section bypass jetected any average eritralned gas volune fractions about $10^{-3}$, which is the range of validity for sucin an instrunient. IE This measurement couplemented the voltage taps in that the voltage taps could detect a single bubble or chain of bubbles, and the nozzle could detect significant average concentrations.

For bolling Inception within the supe theated region, the superieat was evaluated as the highest heater wall terperature within that voltage tap increment alnus the saturation tenperature. When nucleation occurred downstream of the end of the heated length, the superheat was evaluated is the bulk coolant tesperature in that increment ninus the local saturation temperature.

\section{EXPERINESTAL PROCEDURES}

As has been extensively discussed in the 11teracure, -12 incipient bolling data for liquid metals are dependent upon a large number of system paraweters. Therefore, in order to report meaningful date on this phenomenon, it is important that the operating procedures are specified in detall.

1) The operating pressure was set by regulating the pressure in the gas plenum, and the ent1re loop was heated up to $427^{\circ} \mathrm{C}$. This was sccomplished in two different ways:

a) The loop was brought up to temperature by using only the truce and guard heaters. After the tewt section heater was energized, the first boiling tun was taken within 15 ginutes.

b) The test section heater was used in the heatup period in addition to the guard and trace heaters. Linder these conditions, the downstean end of the heated region was at approximately $593^{\circ} \mathrm{C}$ for 2-3 hours. This was by far the highest tenperature in the loop durfing this tise.

2) The flow rate through the test section was set wth the inlet valve. Bolling was achieved by increasing the heat flux in sall increments until inception occurred.

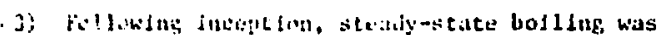

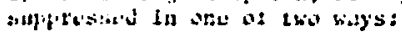

a) If the Insention pherturnenon caused a $20 \%$

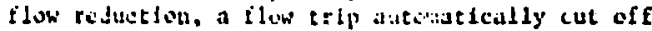

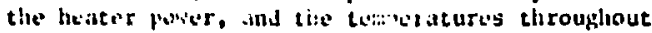
tile test siction yuldily deceyed to $: 27^{\circ} \mathrm{C}$.

b) If (a) did noe vecur, the gower was gradu-

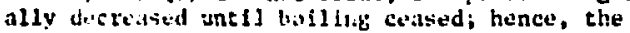
te:ojerature at the end of the hased zune was sifitity less thian the corte'spondling saturation valus.

4) After bolling was suprressed, the gas plenum pressure andiar the test section flow rati were set to new vilues and the nest run was inftiated.

5) For overnigt:t operation, the systen was cooled down to $315^{\circ} \mathrm{C}$, and the bas plenum was then pressurized to 1.05 at:

\section{EXEEIINMT:L RESULTS}

Figure 3 shows a typlcal heater wall temperature profiles in the resion of boiling inception. The heater wall temperatures are calculated from the

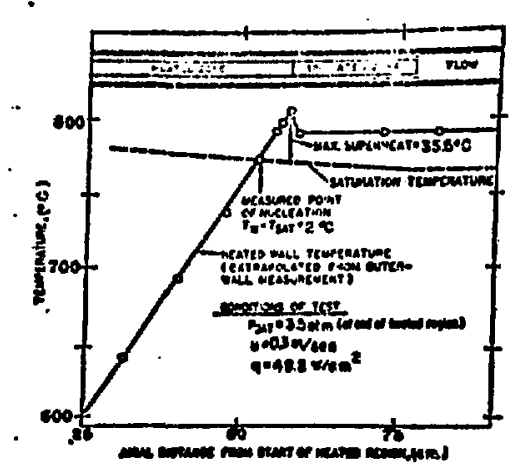

Fis. 3 coolant Temperature Profile

outer wall geasurevents using a Nussele nuber $(\mathrm{hb} / \mathrm{k}$ ) of 6 . The axial location of inception is noted, and it is clear that bolling does not necescarily begin at the point of maximum superheat. Therefore, to definitively evaluate the contribution of any proposed effect, it is essential to know the vall superheat at the point of inception. 14

The convective inciplent-superheat data for a eya- : tem pressure of 0.143 atm are shown in Fig. 5 . The upper sraph is the superheat on the heater wall at the point of inception for all cases in which nucleation occurred within a superheated liquid region. In contrast, the lower graph displays the raxinu superheat in the test section for all runs at this pressure regardless of the type of nucleation. The representation Biven in the lower 1llustration is equivalent to that used by severil previous investigators. $2,4,5$ when the experdmental results are interpreted on the basis of the uiaximum superheat and all nucleations are included, the 


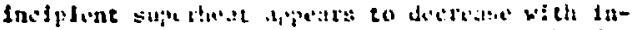

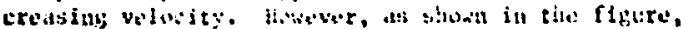

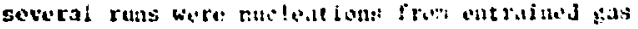

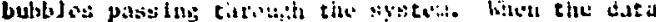

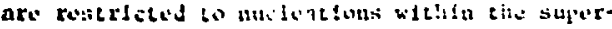

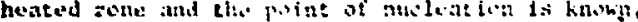
any cependence an syitem volocity is with th the

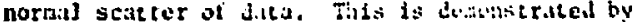
the upper 111:utration in M1s. 4 ind the bifiter

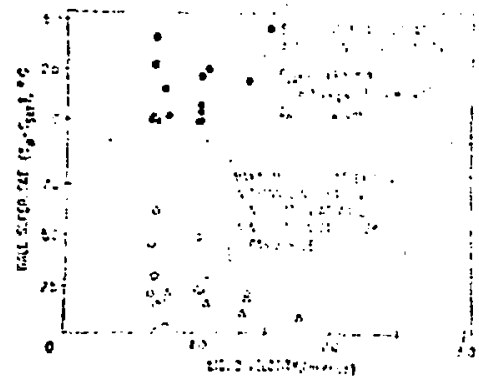

Fig. 4 Incipient Superheats at 6-143 atm.

pressure results given in Fig. 5. As will be subsequently discussed, it is felt that the incinience phenosenon is controlled by parameters not delineaced on Filgs, 4 and 5 .

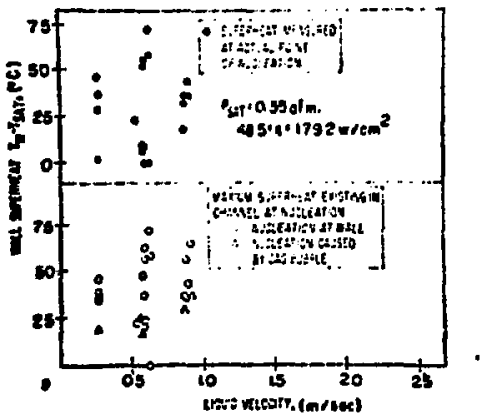

Fig. 5 Incipient Superheats at 0-35 atm.

411 the gas bubble nucleation at $4.5 \mathrm{ft} / \mathrm{sec}$ and below were caused by a single bubble or a single sroup of bubbles passing through aturated or superheated region. For hizher ayster velocities, the tas detection nozzle Indicated a significant average gas volure fraction in the coolant, and for wuch cases, the coolant began bolling at zero bulk superheat.

Iaciplent-botline phenoranon for a given fluid is a complex physical process, and it is not rensonable to expect that the controlling mechanisy for one Flutd also soverns another fluld wich greatly

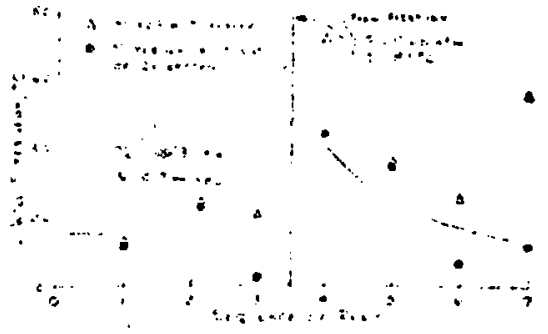

Fig. 6 Surface Deactivation and Reactivation

different themiophysical froperties. 17 The inception criterion recomendad by ilsuli has been successfully applied to suen data tor many ordinary fluids al tinogh one aust stlll be aware of the pressure-temperature history as illustrated by Fabic. Is fowever, the high thermal conductivity of liquid eatals dictates that the tangency cxiterion is not the doninant factor. This was experImentally detwonstrated in kef. 1 by showing that incipient-bolling events induced by heating or depressurization produced tive same initial superheats. (The tangency critcrion is meaning iess for botling due to depressurization.) Holtz, ${ }^{0}$ and Chen ${ }^{8}$ propesed that the pressure-temperature history detersines the cagnitude of Inciplent superheat in a liquid-metal sybtem by dictating the size of the active surface cavities. Experimental data have been reported for sodium and potassiun systems which dewonstrate the effect of pressure-temperature history. $1,3-10$ It has been demonstrated exper1mentally $1,11,12,19$ that once boiling has bieen initiated, the surface can be reactivated (bolling hysteresis), and the effect of the previouls history has been diminished or eresed. Such behavilor was also witnessed in this study and is shown in F18. 6 . Severai successive runs were taken at 0.143 atw and $0.7 \mathrm{~m} / \mathrm{sec}$ and rather low values of superheat were weasured. The system was then exposed to more acvere deactivation condition. The next rin at 0.143 atm required a considerab2y greater íall superheat for inception than the previous buns. However, the history was not reentablished, and the inciplent superhest in the succeeding ruas rapidly decayed back to a value corresponding to the runs whicl. preceded the 0.7 atm hiatory.

In Experimental Procedures, it was pointed out that the facility was brought up to temperature in two different zanners. In particular, method (b) was used on two successive days and on these occasions, comparatively large superheats were neasured for the f1rst iun of each day. In contrast, wethod (a) was employed on the remaining daye and the first run of each day was characterized by low or negative values of inclplent superheat (see Table I). Th1s behavior is indicative of the presence of noncondensable gas in the surface cavities. The gas diffused into the cavites while the system circulated at $315^{\circ} \mathrm{C}$ and 1.05 atm gas plenum pressure 


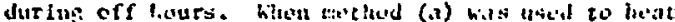
ty tle lowp. the test section was broublit up to bolltm; in a cupaltatively silort thac, and thus,

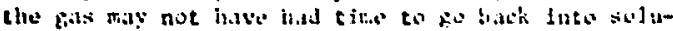

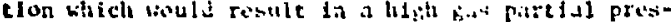

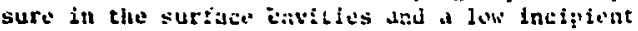

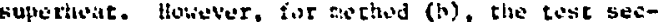

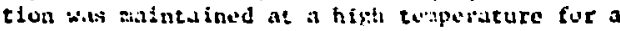
long period bctore the bollint; ruts were inltiated.

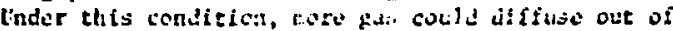

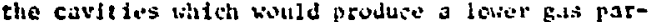
tal pressure and a hlatur ficipient superbas.

\section{TABLE I}

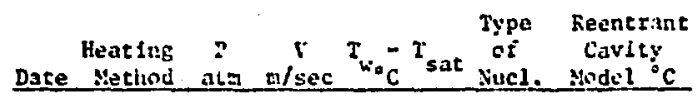

$\begin{array}{rrrrrrr}5 / 11 & \text { a } & 0.21 & 0.32 & 0 & W & 10 \\ 5 / 12 & \text { b } & 0.21 & 0.69 & 61 & W & 53 \\ 5 / 13 & \text { b } & 0.35 & 0.72 & 59 & W & 56 \\ 5 / 14 & \text { a } & 0.14 & 0.67 & -3 & \text { b } & -12 \\ 5 / 14 & \text { a } & 0.21 & 0.66 & 1 & W & 10\end{array}$

- wall nucleation

B - gas-bubble nucleation

To evaluate the gas behavior, it is assumed that the entire sodiun invantory is in equilibrium with the gas plenum at 1.05 atin and $315^{\circ} \mathrm{C}$ (of $\tilde{i}$-hour circulating conditions) as described by Henry's Law.

$C-K(T) P_{8}$

It is furcher assured that during the operating hours there is no mass transfer communication with the gas plenum and also that no gas comes out of colution. As shown in $\ddot{i} 1 \mathrm{~g}$. 1, the argon-sodium interface is removed from the circulatory path and the recked-down portion between the gas disengagement tank and the expansion tank further Impedes sas diffusion. Any noncondensable gas bubbles which circulated through the system probably were entrained at the argon sodiun interface in the heat exchanger. This surface is in equilibrium with the coolunt as specified in Eq. 1. Hence, the gas concentration is assumed constant, or, at equilibrium,

$P_{82}=\frac{K\left(T_{1}\right)}{K\left(T_{2}\right)} P_{81}$

Using the expression given in Ref. 21 for Henry" Ias constant describing the solubility of argon gas In codiun, the gas partial pressures at $427^{\circ} \mathrm{C}$ [aethod (a)] and $593^{\circ} \mathrm{C}$ [wethod (b)] are 0.061 atm and 0.0034 atm respectively. As described above, the heater was brought up to bolling in a comparacively short time which leaves little time for gas to diffuse into the coolant. If it is asumed that the gas is heated at constant volume from $427^{\circ} \mathrm{C}$ to $760^{\circ} \mathrm{C}$ and that no sas diffuses out of the cavity, the gas partial preasure is 0.090 atm for wethod (a). A stailar analysis for method (b) yields a value of 0.0041 ate.

Th1s anplified analysis demonstrates that it is reasonable to expect that heating methode (a) and (b) will produce significantly different cavity conditions in the surface cavities and thus, afsolficantly different superheats.
A.H1.:S1S

As show in the provloits sectlon, the efiuct of a

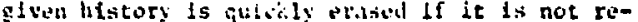

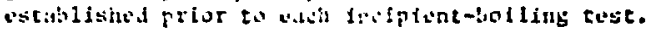

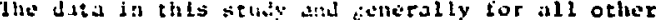

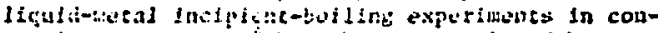

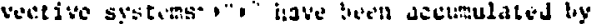

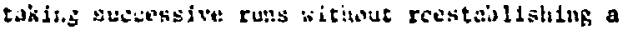

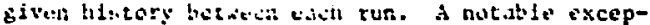

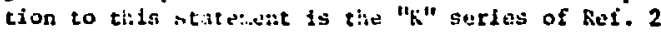
where a spacilic histor wiss applied diter every run and comparatively hi,ith incipient superiteats were consistenty obraimd. This surles of runs - 111 be discussed later.

The various assumptons which can be employed in deriving the pressure-temperature-history nodel for liquld netals are discussed in detafl by holtz. ${ }^{1}$ For the simfla analysis cansidered herein, the reentrant cavity cesiribed by bankoffiz affords a simple, comventent, and highly-illustrative model of the nucleation pheromenon. It is tacitly assuned in this anclysss that reentrant cavities of the required physical dimensions are available.

For the given conditions, the maximum deactivation would be

$r=\frac{2 a\left(T^{+}\right)}{P^{\prime}-\left[P_{v}\left(T^{\prime}\right)+P_{8}\left(T^{\prime}\right)\right]}$

Therefore, the incipient sulerheat under such conditions is expressed as

$$
\begin{aligned}
{\left[P_{v}\left(T_{2}\right)+P_{g}\left(T_{2}\right)\right]-P_{s} } & =\frac{\sigma\left(T_{2}\right)}{\sigma\left(Z^{\prime}\right)}\left(P^{\prime}-\left[P_{v}\left(T^{\prime}\right)\right.\right. \\
& \left.\left.+P_{g}\left(T^{\prime}\right)\right]\right)
\end{aligned}
$$

When a surface has existed at an elevated temperature (590'C or greater) for a couple of hours, the noncondensable gas partial pressure in the cavity can be neglected for cas concentrationa typical of this study.

Assuning that a surface is reactivated after each run, this expression is applicable to data where successive runs are taken without reapplying the deactivation pressure; hence, $P^{\prime}=P$. The deacti-. vation is due to temperature variation. The prediction of Eq. 4 for various deactivation temperatures is shown in FiB. 7 along with the Iaciplent meacurements with sinilar deactivation coaditions from this study, and the agreement is encouraging.

The above prediction 1s based upon the naximum deactivation conddtions. In the preceding section, the role of gas diffusion into the surface cavitiet was outlined, and $1 t$ was shown that the method of heating the loop detcroined the gas partial prescure In the cavities for the firse run of each day. Evaluating the gas partial pressure as outlined above. Eq. 4 can be used to calculate the superheat under these canditions. Table I 11ses the predicclons of the presenure-cenperature-history model for the Intelal runs of each day. The reentrant cavity sodal gives good description of the magnitude and trends of the data Including the negative auperheat observied on $5 / 14$. 


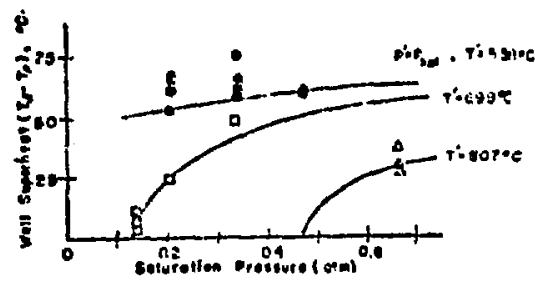

Fig. 7 Heentrant Cavity Predictions

For the " $\mathrm{k}$ " runs reported in fief. 2, the power was tripped follovitg each run end a pressure history was applied prior to the next run. If gas pnrtial pressure is assurted negligible and the history applied just prior to the run is used as the deactivation, a comparison can be affucted between chese experimental results and the prediction of Eq. 4.

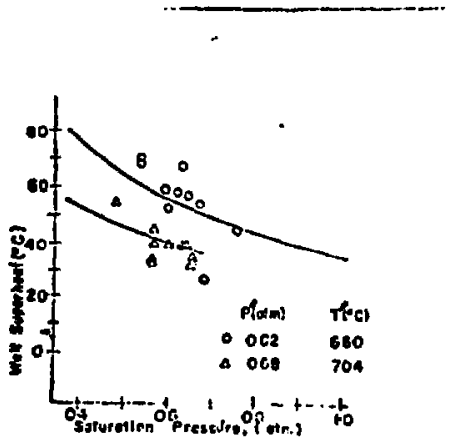

Fis. B Reentrant Cavity Prediction.

The reauleing comparisons are gived in FIt. 8 for wo differeat historles, and the agreement is excellent.

\section{cosclusioss}

1) Any effece of system velocity on the facipient will supetheat, fot the conditions studied, is within the scatcer of the data.

2) then previous hiscory and noncondensable gases ore properly accounted for, the reentrant cavity aodel provides a rellable estimate of the incipient wall supe theat.

\section{BEREMES}

fl/ tlalez, K. L.. lh.t. Thesds, Xorthiostern l'niversity (19)?l).

/2/ l.sin, U., C. J. : Irutay, J. A. Lusndont, and

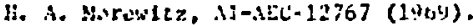

/3/ Logan, b., C. J. Liardizy, J. A. Liation, and

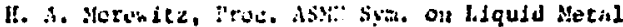
llest gransfor and iluld byati.ics (1970).

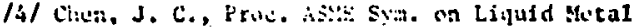

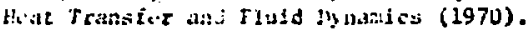

/5/ Pezzilli, M. A. Easec, J. Searano, G. Turassetti, and b. C. Finctiera, Proc. ASAE Syt. on l.Iglidd Silal liest Transter and Fluld Dynanics $(1970)$.

(6/ Koctonski, th. and G. Grass, Proc. ASyE Sam. on If guid Netal Hest Transfor and Fluid Dynamics (1970).

/7/ Schulteiss, G. F., Proc. ASNe Syel. on Liquid Yetal Heat Trunster and Fludd Djnanics (1970).

f8/ Chen, J. C., Trans, s5.4E (lleat Trans.) 90, 303 (1068).

/9/ Holtz, R. E. and S. M. Singer, AsL-7609 (1969),

$/ 10 /$ Holkz, R. E. and K. N. Singer, NLL-7383 (1967).

/11/ Edwards, J. A. und H. W. liof fwan, Proc. JSNE Seni-Incernational Sy.., Heat Transfer, II (1968).

/12/ Marto, P. J. and W. M. Rohsenow, Trans. ASME (Heat Transfer) $8 \mathrm{~s}-C_{1} 196$ (1966).

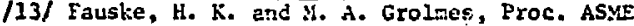
Sym. on Liquid Nietal hieat Transfer and Fluid Dynasics (1970).

$114 /$ Fauske, H. K., R. E. Holtz, and R. M. Singer, Trans. ANS, 14, 238 (1971).

/15/ Kottowsk1, H., G. Grass, R. Warnsing, and A. Blrke, Presentation 2nd lecting of Iiquid Netal Boiling hork Group, Casaccia Nuclear Center, Rone, Italy (1970).

/16/ Henry, R. E., Trans. Als, 14, 277 (1971).

/17/ Volir, J. H. and T. ChIang, ITI-69TR45 (1969).

/18/ Hsu, Y. Y. and R. W. Graham, NASA TS-D-594 (1961).

119/ Fabic, S., Ph.D. Thesis, Univertity of Callbornfa (1964).

/20/ Holt2, R. R., ANI-7184 (1966).

121/ Veleckis, E., K. Bloomquist, R. Yonco, and H. Rerin, ANiL-7325, 128 (1967).

/22/ Bankoff, S. G., "Cocurrent Gas-1iquid Flow," Edited by Rhodes and Scott, Plenum Prese, 238 (1969). 